\title{
Mission on the margins: A proposal for an alternative missional paradigm in the wake of COVID-19
}

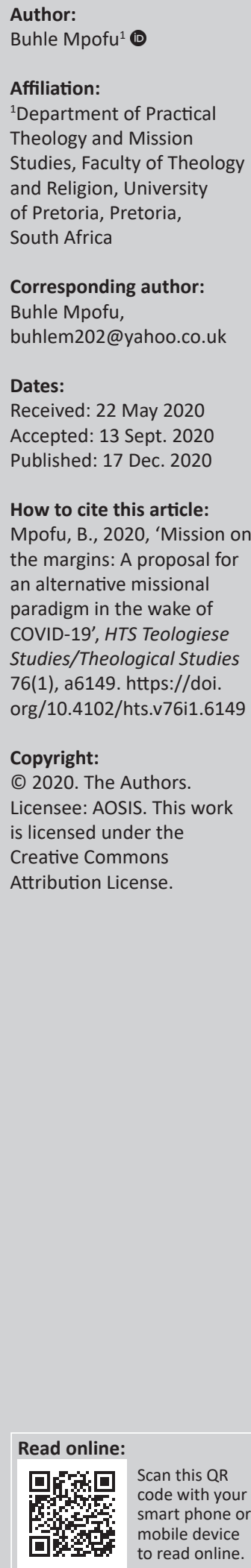

This article proposes a critical paradigm to identify missional areas that have received scant attention from the church and to theorise ways in which alternative modes of doing mission in the context of coronavirus disease 2019 (COVID-19) present a solution against tendencies which marginalise and exploit the poor. Examining ways in which local churches in South Africa responded to challenges posed by COVID-19, the article identifies socioeconomic challenges that have been neglected by the church to posit that COVID-19 has disrupted traditional practices and exposed missional blind spots. Building on Keum's ideas of 'reversal of roles' and a shift of the mission concept from 'mission to the margins' to 'mission from the margins', the article notes that shifting of religion from public to private sphere as a result of COVID-19 will redefine the church and proposes that church mission should be located where the poor people are. The article concludes that COVID-19 disruptions allow for emergence of alternative ways of being church and new modes of socioeconomic organisation with new possibilities presented through an alternative theoretical hermeneutics of missiology that locates experiences of the poor at the centre.

Contribution: This article represents a systematic and practical reflection within a paradigm in which the intersection of philosophy, religious studies, social sciences, humanities and natural sciences generate an interdisciplinary, multidisciplinary and transdisciplinary contested discourse.

Keywords: COVID-19; Mission of the Church; paradigm shift; critical theory; South Africa.

\section{Introduction}

The outbreak of coronavirus disease 2019 (COVID-19) global pandemic paralysed all aspects of human lives and transformed systems, cultures, businesses and institutions as communities grappled to stay safe from the deadly COVID-19. The existential desire for safety and shunning precarious situations prompted the need to delimit spaces we inhabit, as governments ordered lockdowns and closed borders as part of measures to curb the spread of the virus and fast track 'contact tracing'. Demarcating territories through 'stay at home' instructions and regulations restricted travelling to essential services. The global threat presented by COVID-19 resulted in one of the worst socioeconomic disruptions in modern history, leaving a devastating impact and configuring the world in a scale never imagined before. As infections and deaths peaked, most countries introduced a lockdown and millions of jobs were lost; universities, schools, colleges and Technikons remained closed; oil prices plunged to critical levels and global trade was estimated to decline by $32 \%$ in 2020 (CNN 2020).

It all started in January 2020 when China reported an outbreak of an 'unknown flu' which was discovered in Wuhan in December 2020 and forced the Chinese government to lock down Wuhan in a bid to quarantine suspected cases. The virus spread outside of China, first hitting European countries before spreading to other parts of the world. On 05 March 2020, the South African National Institute for Communicable Diseases (NICD) confirmed that the first suspected case of COVID-19 had tested positive (NICD 2020) and by this time, the disease had spread globally, with multiple deaths reported (NICD 2020). On 11 March 2020, merely 6 days after the first reported case in South Africa, the World Health Organisation (WHO) declared COVID-19 a pandemic, reporting that the first case of coronavirus (patient-zero) can be traced back to a diagnosis made on 17 November 2019 in Wuhan, China (WHO Briefing, 11 March 2020).

In South Africa, the initial 21-day lockdown was announced on 26 March 2020 as churches were preparing for traditional annual Easter celebrations. As part of the lockdown measures, religious

Note: Special Collection entitled COVID-19 from a Theological Perspective, sub-edited by Jerry Pillay (UP). 
gatherings were prohibited. Worship services and pilgrimages were suspended, forcing church activities to come to a standstill. Consequently, there was confusion in some religious communities given that Christians were traditionally used to annual Easter celebrations. It became apparent that the world was dealing with an unprecedented challenge and within 3 months, COVID-19 had impacted on all aspects of our lives. The church had to explore new ways of doing mission in the context of isolation, trauma and disruptions.

A message posted by the Health and Wellness cluster at the University of Pretoria provided tips for coping with the challenges posed by social distancing in the context of limiting the spread of coronavirus, and quoted Voktor E. Frankl (2006): ‘[w]hen we are no longer able to change a situation, we are challenged to change ourselves'. During the time of social distancing (Employee Wellbeing Programme at UP, 20 April 2020):

[W]e are not only challenged to change ourselves and the way we look at the situation, but we are also challenged to connect in new and creative ways - connection to self, others and the world around us. (p. 1)

In a volume titled Topography of Trauma: Fissures, Disruptions and Transfiguration (Schaub et al. 2019), scholars also observed that:

$[T]$ o ward off chaos, human beings strive to control their spatial environment. Reflecting their existential desire for safety and for shunning precarious situations, they need to delimit the place they inhabit, the realm they move into, in a manner akin to the nomads' custom of laying down a carpet to demarcate the territory that grounds their home ... Feeling secure, therefore, emanates from the circumscription of the space inhabited and the knowledge that it does not involve any danger, that it has become a place whose parameters grant safety. (p. 2)

\section{Conceptual framework}

This article employs the classic definition of mission by Leslies Newbigin (1960) which asserts that:

[T] he mission of the church is everything that the church is sent into the world to do: preaching the gospel (Kerygma), healing the sick, caring for the poor, teaching the children, improving international and interracial relations, attacking injustice ... and to plant churches through evangelism. (p. 911)

Drawing on this definition, the article highlights the shifting of religion from public to private sphere as a result of COVID-19 to propose a new missional paradigm characterised by a 'reversal of roles' and a shift of the mission concept from 'mission to the margins' to 'mission from the margins', as observed by (ed. Keum 2013:5). By discussing alternative modes of doing mission with the poor in the context of COVID-19 through these lenses, the article proposes that given the space of the church in traditional buildings has been disrupted, church missions should be located where people are - especially the poor and marginalised communities.

\section{Coronavirus disease 2019 and its impact on the church: Attending to missional blind spots}

As lockdowns forced nations to demarcate their territories, in a bid to stay safe that grounds, closed borders and emergency responses to COVID-19 also meant that religious institutions had to cooperate with the state as churches, mosques, temples and shrines were ordered by governments to shut down. Social media was abuzz with circulated videos of worshippers and religious leaders raided by police and security forces as some faith communities defied lockdown orders. For example, in South Africa, there was a video circulated showing a bride and the groom taken into police custody and their minister and guests arrested for violating lockdown regulations given that the government had limited gatherings only for funerals with a maximum number of 50 attending (Rabkin 2020:1).

In addressing the implications of changes on traditional church practices as a result of COVID-19, this article conceptualised 'mission' (Bosch 1991:12) as 'the participation of God's people in God's mission to renew the whole of creation and the lives of all its people and cultures in their totality' (Goheen 2014) and approached missiology as a focus on systematic study of all aspects of mission (Skreslet 2012) and the comprehensive fullness of life from the perspective of salvation in Christ (Verster 2014:882).

Considering that ' $[t]$ he world today is massively religious' (Berger 1999:9), it came as no surprise that there were religious leaders like Bishop Ngcobo who questioned the government's authority over shutting down of religious gatherings and defied lockdown regulation (Maharaj 2020:1). However, most of the South African religious communities complied with government regulations and shut down religious activities. The majority of people were more concerned about social and economic activities than with the disruption of religious activities and this raises questions on whether secularisation has overtaken previously religious communities like what has been seen in Europe where 'secularization has made non-religiousness the default option' (Houtman 2020). Although some parts of the world like Europe may be considered 'anything but the secularized world that had been predicted' (Berger 1999:9), it is important to note that ' $[t]$ he old secularization theory might be true in some instances', but in general, the theory that 'secularity will triumph' has been 'unpersuasive' (Berger 1999:12) and the 'massively secular Euro-culture' exemplifies 'widespread alienation from the organized church' or 'a shift in the institutional location of religion' (Berger 1999:10). This shift was illustrated in the privately celebrated Easter during the lockdown period and raises an important question: What are the implications of such a shift in the institutional location of religion in South Africa? Given these changes, another question arises on whether the 
broader mission of the church can still be effectively realised in private fellowship with little contact with the rest of the world. For example, a classic definition of mission by Leslies Newbigin (1960) asserts that:

[T] he mission of the church is everything that the church is sent into the world to do: preaching the gospel (Kerygma), healing the sick, caring for the poor, teaching the children, improving international and interracial relations, attacking injustice ... and to plant churches through evangelism. (p. 911)

The above definition highlights something essentially flawed with limiting church activities within religious and private spaces because mission is essentially 'participation' in various life-affirming activities of our local communities. Therefore, the suspension of religious activities during the lockdown periods should have only shifted the mission of the church from public to the private spheres of life and not paralysed the church as it did. I wish to highlight areas that have been neglected in church's mission to demonstrate how shifting of religious practices from public to private sphere as a result of COVID-19 presents an opportunity to attend to these 'blind spots'.

It will take long to develop a vaccine to cure COVID-19 and there is a need for a paradigm shift from normal life in the context of extended 'social distancing' measures. Religion should be primarily concerned with understanding reality (Beyers 2010:1), and the changes necessitated by the threat of coronavirus will require a missional shift to address the limits of traditional practices and pay attention to emerging challenges such as the experiences of foreign migrants in South Africa (Mpofu 2019; Mpofu \& Settler 2017). ${ }^{1}$ In the section 'A virtual and digital church - Exclusion of the poor', I highlight some perspectives on the impact of COVID-19 on mission of the church.

\section{A virtual and digital church - Exclusion of the poor}

In an article published by Tshegofatso Mathe (07 May 2020), Reverend Thembelani Jentile, a minister at the Mamelodi Baptist Church, shared his experiences of how churches are struggling in lockdown. He explained how he, like most ministers affected by lockdown, has been relying on digital technology to preach over social media since the beginning of the lockdown. Moving Sunday services from church gatherings to cyberspace impacted on offerings and his congregation could not afford to provide meals for the poor and displaced. His experience is consistent with what I observed amongst ministers within the Uniting Presbyterian Church in Southern Africa (UPCSA).

1.These publications reviewed trends in religion and migration in South Africa and thematically discussed recent developments in the field of religion and migration studies. 'Migration, xenophobia and resistance to xenophobia and socioeconomic exclusion in the aftermath of South African Rainbowism' (Mpofu 2019) examined recent statements by South African political leaders to demonstrate a examined recent statements by South African political leaders to demonstrate a tendency to draw a stark distinction between citizens. Responses to COVID-19 laid thes distinctions bare as the government provided support to local citizens and completely neglected unemployed non-South African migrants who were left destitute - despite admissions that lockdowns affected livelihoods of all people in the informal econom sector. The article reviewed trends in religion and migration in South Africa and thematically discussed recent developments in the field of religion and migration studies to demonstrate how migrants navigate marginalisation.
Although a few churches continued to receive pledges through bank transfers as their mission on the margins supported poor communities through food distribution packages permitted under essential services, most congregations reported dwindling financial resources as they were not receiving offerings from the majority of people who could not make electronic bank transfers. Mission from the margins has been described by Goheen (2014) as mission in weakness and suffering. Congregating in small numbers or meeting and preaching in cyberspace should not discourage church leaders from seeing the church differently. ${ }^{2}$ Given that experts warn that coronavirus may never go away any time soon (WHO 2020), there is a need for a fundamental shift in our way of life and religious practices. Addressing the nation on the 13 May 2020, South African President Cyril Ramaphosa (13 May 2020) highlighted some of these necessary changes in life and worship:

[T] here needs to be a fundamental shift in our thinking and our way of life ... [we] will need to re-organize workplaces, schools, universities, colleges and other public places to limit transmission ... We will need to adapt to new ways of worshipping, socializing, exercising and meeting.

There is an emerging normal defined by a shift from public worship to private digital-based platforms. The challenge with digitalising of preaching and pastoral work is that the poor will be excluded from the church as the majority cannot afford Internet and electronic gadgets. Therefore, there is an urgent need for new ways of ministering to the poor in the context of COVID-19. It is also important to consider that although social distancing and washing of hands with clean water and soap are effective means of preventing infection, this strategy is elitist. For the people crowded in informal settlements, it does not make sense and is not practical to implement.

\section{The challenge of prosperity gospel: Exploitation of the poor}

Soliciting for money is at the core of most religious practices and controversial for the African church as a result of 'prosperity gospel' abuses and exploitation of the poor. ${ }^{3}$ Whilst the Bible encourages giving according to what each 'purposes in his heart, not reluctantly or under compulsion, for God loves a cheerful giver' (2 Cor 9:7), some churches have been thriving with the theology of prosperity where the poor and unemployed are forced to give in order to sustain lavish lifestyles of the elite leaders. During the lockdown in South Africa, the government announced a R5 billion stimulus package to support companies and unemployed South Africans who are not receiving grants. Although it is well documented that the majority of affected people in the informal sector were non-South Africans, it came as no surprise that migrants were excluded

2.There is a need to separate mobilisation of financial resources from understanding who and what constitutes the church.

3.For example, see https://www.desiringgod.org/articles/the-gods-of-the-prosperitygospel. 
(see Mpofu 2019) ${ }^{4}$ from this emergency intervention. Churches and non-government organisations had to provide food parcels to millions of starving people. However, it was encouraging that not all South African citizens were hostile towards migrants. One of my studies found that some Christians and local congregations are not comfortable with the presence of African migrants in their communities and congregations (see Mpofu 2018).

It is understood, like any organisation, churches have administrative costs and need to pay salaries, and during the lockdown, some were forced to pay a living wage. Under these circumstances, giving should be encouraged although churches should guard against the exploitation of the poor by pastors living luxuriously. Such practices needed to be disrupted through the suspension of traditional church gatherings and this provides an opportunity to re-examine these exploitative practices. As digital ministry replaces traditional church gatherings in line with social distancing measures, more congregants will place value on smaller local cell groups than mega churches. This will lead to a new church-funding models where people are reluctant to maintain church building in favour of missional programmes. It did not have to be like this.

\section{Church membership is not church attendance}

The normal practices which align collection of tithes and pledges to church attendance need to be revisited in the context of shifting to a digital church. Church membership should be based on baptism and confession of the lordship of Jesus Christ as opposed to attending church services. Therefore, it must be emphasised that to be involved in God's mission is to participate in Trinity and community of believers (koinoia). Such an understanding of church membership as participation in God's mission will encourage reaching out to marginalised communities and faithful electronic giving in the age of an emerging virtual digitally orientated postCOVID-19 church. As Keum (ed. 2013:5) also observes, marginalised people play an equally important role in God's mission, and the disruptions caused by COVID-19 necessitate a 'reversal of roles' and shift of the mission concept from 'mission to the margins' to 'mission from the margins'.

The post-COVID-19 church should emerge as a church whose mission is God's mission (missio-dei) not merely the activities of the church where the poor are marginalised and exploited by the rich and powerful. Solidarity with the poor should be the essence of being church, the 'inspiring, transforming, lifegiving work of the Holy Spirit' (Kim 2009:30) who initiates,

4.This article maps the changing fortunes of migrants in South Africa during the las 25 years of democracy and contends that whilst many migrants moved to South Africa because it presented hope for democracy, civil protections from ethnic division, opportunity and inclusion, the opportunities and recognition of migrants remain an elusive dream. This article examines the different articulations of South African Rainbowism through interrogating the place of migrant in the various structural or economic development policies from Mandela's Reconstruction structural or economic development policies from Mandela's Reconstruction and Development Programme (RDP), through Mbeki's Growth, Employment and Redistribution (GEAR), Zuma's Radical Economic Transformation (RET) and more recently Ramaphosa's Thuma Mina dispensation. The article observed marginalisation ' 'South Africa belongs to all who live in it, united in our diversity', the socioeconomic privileging of citizens over migrants impede on the realisation of a just post-apartheid society. guides and empowers the Church's mission towards fullness of life (oikodome). It did not have to be like this; we should never have linked church membership with church attendance in our Christian teaching and mission practices. Therefore, there is a need to encourage families to spend more time together as they did during COVID-19 lockdown period, as a community-based extension of the kingdom of God.

\section{Poverty and domestic violence}

During the lockdown period, some of the social ills which were laid bare included poverty, marginalisation and escalation of domestic violence. These 'missional blind spots' increased with indoor family life during the lockdown period. As global economic depression and unemployment levels sky rocketed, livelihoods of most poor families were affected. According to United Nations Human Rights Council (UNHRC) report published on 22 April 2020, many governments' responses to COVID-19 have had a devastating effect on people in poverty (Philip Alston, UN Special Rapporteur):

$[D]$ espite often far reaching policy reversals and huge financial support packages, the most vulnerable have been short-changed or excluded ... [t] $t$ he policies of many States reflect a social Darwinism philosophy that prioritizes the economic interests of the wealthiest, while doing a little for those who are hard at work providing essential services or unable to support themselves.

Alston added that COVID-19 could push an additional more than half a billion people into poverty and International Labour Organisation (ILO 2020) estimated that 200 million full-time jobs will be lost in the coming months. Increased levels of poverty and unemployment are drivers of violence against women and children, particularly in poor communities and South Africa has one of the world's highest rates of crime and sexual assaults (Stats SA 2016). In the past 3 months, risks of violence against women and children increased during the lockdown period because of the following reasons: more time spent at home with abusers, rising stress, isolation from social support networks and limited access to critical services (WHO 2020). Even as ministers continued to preach online, it became clear that churches had no long-term strategy to address poverty and domestic violence.

\section{Ecological and economic justice as means to address poverty in the new order}

Given the evidence that God's involvement in history has always demonstrated how he draws humanity and all of creation into communion with him, the crisis of the novel coronavirus is a significant historical moment that will transform the world. According to the International Energy Agency (IEA 2020), global carbon emissions will probably drop by $8 \%$ in 2020, the largest decline since World War II. The virus has disrupted normal life by forcing global economies to shut down as billions of people are under lockdown, resulting in lesser ecological destruction. Although this is a welcome ecological development, it came at a huge 
human cost - with at least a quarter of a million people dead, overstretched health systems, mass unemployment, poor communities disproportionately impacted and a crumbling global economic system. COVID-19 has 'exposed something broken to the core' (Mail and Guardian 08 May 2020); the current global economic system is not only destructive to the environment, but it thrives on inequalities and marginalises the poor - this did not have to be like this.

Economic and ecological justice should drive the mission of the church in the emerging post-COVID-19 economic order. Although economic justice has been on the church's agenda through themes of ecodomy ${ }^{5}$ and eco-justice, ${ }^{6}$ faith-based communities only recently started exploring ecological justice themes to appropriate God's mission in a cosmic sense, and approach mission holistically by affirming all life, the whole oikoumene, as being interconnected. A study by Niemandt and Pillay (2015:35) on trends in ecumenism and mission examined four significant ecumenical events of the new millennium and concluded that what 'perhaps typify the most important missional and ecumenical trend', is the unequivocal commitment to ecological justice issues. In responding to the post-COVID-19 economic and ecological challenges, churches should build on these ecumenical projects as a holistic missional approach which affirms all life, life in its fullness - a focus that has rightly been identified as a faculty research theme at the University of Pretoria (see Niemandt \& Beyers 2017).

\section{Fundamental shifts to the margins}

The fundamental shift identified by the South African president is also necessary for the ways in which we do mission. There was no need for the church to wait until the pandemic struck before we could seriously respond to the challenges faced by the poor. We should have never allowed such levels of poverty, xenophobia and domestic violence to be normalised in our communities. Asserting to the opportunity presented by COVID-19 to restructure of economy, the South African Council of Churches made this clarion call (SACC 2020):

$[W]$ e say, together we can and shall rebuild our economy, but that the resolve must be for an inclusive economy, making our reality of two separate economies - 'formal' (mainly white and rich) and 'informal' (mainly black and poor), the matter of a preCOVID past. We must now plan and work for a restructured post-COVID inclusive economy with validated contributions from all, and benefits for all.

Secondly, the crisis presented by COVID-19 challenged church practices and pushed its mission to the margins, where the people are and this is an invitation for church leaders and theologians to explore new ways of being church as we adjust to the new normal. Whereas the church has been commissioned 'into the world to do: preaching [of] the

5.According to Niemandt (2015:1), economy in mission refers to the growing attention to earth-keeping and life in fullness in missiology.

6.Faramelli (2015:151) defines eco-justice as a comprehensive term which includes ecology, economy and equity. These themes are critical at this time given the unjus global economic systems which perpetuate inequalities and lead to destruction of environment. gospel, healing the sick, caring for the poor, teaching the children, improving international and interracial relations, attacking injustice' (Newbigin 1960:21), the church tended to be isolated from the local communities. This is evident in most congregations focusing their pastoral care to members as opposed to ministering to local communities.

Thirdly, the church should emerge from COVID-19 well equipped for a new age of mission. COVID-19 disruptions present an opportunity for emergence of alternative ways of being church and new modes of socioeconomic organisation. Therefore, we need an alternative theoretical hermeneutics and missiology that locates experiences of the poor at the centre, rehabilitating the human conditions by reverse order, as Griffith (2019) noted:

[W]e must go sharply into reverse ... We must rehabilitate ourselves; get our old natural selves to join with our other conscious, wilful [sic], rational, scientific selves [reconcile our original natural instinctive self or soul with our newer psychologically troubled conscious self]. Again, the message is that to make any progress in our human situation we had to solve the human condition. (p. 10)

\section{Conclusion}

This article engaged a critical paradigm to identify missional areas that have received scant attention from the church and to theorise ways in which alternative modes of doing mission in the context of COVID-19 can serve as disruptions against tendencies which marginalise and exploit the poor. The article identified poverty, prosperity gospel and domestic violence as 'missional blind spots' and argued that these socioeconomic challenges have been largely neglected by the church. By disrupting traditional self-serving practices of the church, COVID-19 presents an opportunity for a paradigm shift for us to 'go sharply into reverse ... [and] rehabilitate ourselves [and] restore our old natural selves'. Such transformation will require a multidisciplinary approach which takes our African context and the experiences of the poor seriously. There is a need for liberation theologies to engage seriously with social scientists and policy makers through a multidisciplinary interrogation of social and missional practices to ensure that religious spaces and communities rediscover their sacredness as places of liberation and transformative restoration grounded on lifeaffirming theologies which boldly empower the church to denounce life-denying practices.

\section{Acknowledgements}

The author acknowledges the generous contributions from eThekwini Presbytery WhatsApp group conversations and meetings and the guidance and statements issued by the South African Council of Churches (SACC) and the Uniting Presbyterian Church in Southern Africa (UPCSA) during the COVID-19 lockdown period.

\section{Competing interests}

The author has declared that no competing interest exists. 


\section{Author's contributions}

B.M. is the sole author of this research article.

\section{Ethical consideration}

Ethical approval to conduct the study was obtained from the Research Ethics Committee of the Faculty of Theology and Religion, University of Pretoria, on 21 April 2020 (Ethical Clearance number: T027/20)

\section{Funding information}

This research received no specific grant from any funding agency in the public, commercial or not-for-profit sectors.

\section{Data availability statement}

Data sharing is not applicable to this article as no new data were created or analysed in this article.

\section{Disclaimer}

The views and opinions expressed in this article are those of the author and do not necessarily reflect the official policy or position of any affiliated agency of the author.

\section{References}

Berger, P.L., 1999, 'The desecularization of the world', in P.L. Berger (ed.), The desecularization of the world: Resurgent religion and world politics, pp. 1-18, WB Eerdmans Publishing Company, Grand Rapids, MI.

Beyers, J., 2010, 'What is religion?: An African understanding', HTS Teologiese Studies/ Theological Studies 66(1), Art \#341. https://doi.org/10.4102/hts.v66i1.341

Bosch, D.J., [1991] 2006, Transforming mission: Paradigm shifts in theology of mission, 22nd edn., Orbis Books, New York, NY.

Cable News Network (CNN), 2020, Live News Broadcast, 09 April.

Faramelli, N., 2015, 'Missio Dei and eco-justice and earth care: Asking hard questions', in K.J. Kaoma (ed.), Creation care in Christian mission, pp. 148-164, Regnum Books, Oxford. (Regnum Edinburgh Centenary Series 29).

Frankl, V.E., 2006, Man's search for meaning, Beacon Press, Boston, MA.

Goheen, M.W., 2014, Introducing Christian mission today: Scripture, history and issues, Kindle edn., InterVarsity Press, Downers Grove, IL.

Griffith, J., 2019, Transform your life and save the world through the dreamed of arrival of the rehabilitating biological explanation of the human condition, WTM Publishing, Sydney, Australia.

Houtman, D., 2020, After secularization: Unbelief in Europe, viewed 11 September 2020 from https://www.religiousstudiesproject.com/response/after-secularizationunbelief-in-europe/.

ILO., 2020, As job losses escalate, nearly half of global workforce at risk of losing livelihoods, viewed 11 September 2020, from https://www.ilo.org/global/aboutthe-ilo/newsroom/news/WCMS_743036/lang--en/index.htm.
International Energy Agency., 2020, Global energy and CO emissions in 2020 viewed 14 September 2020, from https://www.iea.org/reports/global-energyreview-2020/global-energy-and-co2-emissions-in-2020.

Kim, K., 2009, Joining in with the Spirit: Connecting world church and local mission, Epworth, London.

Keum, J. (ed.), 2013, Together towards life: Mission and evangelism in changing landscapes, with a practical guide, World Council of Churches Publications, Geneva.

Lesslie, N., 1960, 'Mission and Missions,' Christianity Today 22(4), 911.

Maharaj, J.M., 2020, 'Bishop Bheki Ngcobo arrested for allegedly defying lockdown', IOL News, 04 May, viewed 20 May 2020, from https://www.iol.co.za/news/southafrica/kwazulu-natal/bishop-bheki-ngcobo-arrested-for-allegedly-defyinglockdown-47510556 for a story on the Bishop who was arrested for defying lockdown regulations.

Mail and Guardian, 05 May 2020, viewed 08 May 2020, from https://mg.co.za/ business/2020-05-07-churches-are-struggling-in-lockdown/.

Mpofu, B., 2018, 'Church as hostile, host or home: Sociological and theological perspectives on migration in Johannesburg, South Africa', Alternation Journal 22(1), 103-118. https://doi.org/10.29086/2519-5476/2018/sp22a6

Mpofu, B., 2019, 'Migration, xenophobia and resistance to xenophobia and socioeconomic exclusion in the aftermath of South African Rainbowism', Alternation 26(1), 153-173. https://doi.org/10.29086/2519-5476/2019/v26n1a7

Mpofu, B. \& Settler, F., 2017, 'The limits of social responsibility with respect to religion and migration in South Africa', Journal for the Study of Religion 30(2), 12-31.

NICD, 2020, First case of COVID-19 coronavirus reported in SA, viewed 11 September 2020, from https://www.nicd.ac.za/first-case-of-covid-19-coronavirus-reportedin-sa/.Niemandt, C.J. \& Beyers, J., 2017, 'Science of Religion and Missiology at the Faculty of Theology, University of Pretoria: Historical overview, theological discourses and future possibilities', Verbum et Ecclesia 38(4), suppl. 2, a1663. https://doi.org/10.4102/ve.v38i4.1663

Niemandt, C.J.P. \& Pillay, J., 2015, 'Trends in ecumenism and mission: Four significant ecumenical/missional events from 2010-2013', Reformed World 65(1), 31-50.

Rabkin, F., 2020, 'Rules for lockdown: Stay put', Mail and Guardian, 26 March, viewed 11 September 2020 from https://mg.co.za/article/2020-03-26-rules-for-lockdownstay-put/.

Ramaphosa C.M., 2020, Statement by President Cyril Ramaphosa on South Africa's response to the corona virus pandemic. Union Buildings, Tshwane 13 May, 2020, viewed 11 October 2020, from: http://www.dirco.gov.za/docs/speeches/2020/ cram0513.pdf.

Schaub, D., Linder, J., Novak, K., Tam, S.Y. \& Zaniniolume, C. (eds.), 2019, Topography of Trauma: Fissures, Disruptions and Transfigurations, Brill, Leiden, Netherlands.

Skreslet, S.H., 2012, Comprehending mission: The questions, methods, themes, problems, and prospects of mission, Orbis Books, New York, NY.

South African Council of Churches (SACC), 2020a, Coronavirus pastoral plan, SACC statement, SACC, Johannesburg.

South African Council of Churches (SACC), 2020b, A general pastoral letter to the Churches from the leaders of SACC member Churches in COVID time.

Stats SA (Statistics South Africa), 2016, Crime statistics series volume III: Exploration of selected contact crimes in South Africa. In-depth analysis of victims of crime survey data: 2011-2014/15, Statistics South Africa, Pretoria, viewed 14 May 2020, from www.statssa.gov/publications/report-03-40-01/Report-03-40-012015.pdf.

Tamfu, D., 2020, The Gods of the prosperity Gospel: Unmasking American idols in Africa, viewed 21 May 2020, from https://www.desiringgod.org/articles/thegods-of-the-prosperity-gospel.

The New York Times, n.d., Coronavirus 'May never go away', a Top W.H.O. official warns, viewed 14 May 2020 from https://www.nytimes.com.

Verster, P., 2014, 'Missiology: Rise, demise and future at the university', Nederduitse Gereformeerde Teologiese Tydskrif 55(3\&4), 879-893. https://doi.org/10.5952/553-4-670 